\title{
Density and rheological inhomogeneities in the mantle of the active oceanic margins of western part of Pacific Ocean and the Kuril deep-sea trench area
}

\author{
Rustam F. Bulgakov* \\ Vladimir N. Senachin \\ Maksim V. Senachin
}

\author{
Institute of Marine Geology and Geophysics, FEB RAS, \\ Yuzhno-Sakhalinsk, Russia \\ *E-mail: r.bulgakov@imgg.ru
}

\begin{abstract}
Rus PDF
Recent knowledge of active oceanic margins with using of geodynamic simulations under constraints of gravity anomalies is analysed in this work. The aim of the analytical review is estimation of density and viscosity distribution in the subduction zones of the well investigated deep trenches of Pacific Ocean. The comparative analysis allows to apply these parameters estimations to the Kuril subduction zone. For the deep structure of the Kuril trench subduction zone the average excess of descending slab density versus the mantle layers at the same depths in the range for $0.02-0.05 \mathrm{~g} / \mathrm{cm}^{3}$ can be expected. The mantle viscosity varies in the range from maximum $1023 \mathrm{~Pa}$ s within the lower layers to $1019 \mathrm{~Pa}$ s inside the low viscosity wedge. The viscosity of the descending slab decreases with the depth. The astenosphere viscosity is probably by 10 factor higher than low viscosity wedge. Low viscosity wedge of the Kuril transition zone should be big enough to be the cause of back-arc spreading and the Kuril deep-sea basin forming. The geoid anomalies are the significant additional informative source for investigation of the deep structure of the transition zones.
\end{abstract}

\section{Keywords}

low viscosity wedge, geoid, subduction, Kuril zone

For citation: Bulgakov R.F., Senachin V.N., Senachin M.V. Density and rheological inhomogeneities in the mantle of the active oceanic margins of western part of Pacific Ocean and the Kuril deep-sea trench area. Geosystems of Transition Zones, 2020, vol. 4, no. 1, p. 116-130. (In Russian).

https://doi.org/10.30730/2541-8912.2020.4.1.116-130

Для цитирования: Булгаков Р.Ф., Сеначин В.Н., Сеначин М.В. Плотностные и реологические неоднородности мантии активных океанических окраин западного сектора Тихого океана и зоны Курильского глубоководного желоба. Геосистемы переходных зон. 2020. Т. 4, № 1. С. 116-130. https://doi.org/10.30730/2541-8912.2020.4.1.116-130

\section{References}

1. Billen M., Gurnis M. 2003. Comparison of dynamic flow models for the Central Aleutian and TongaKermadec subduction zones. Geochemistry, Geophysics, Geosystems, 4(4). https://doi.org/10.1029/2001gc000295

2. Billen M., Gurnis M., Simons M. 2003. Multiscale dynamics of the Tonga-Kermadec subduction zone. Geophysical J. International, 153(2): 359-388. https://doi.org/10.1046/j.1365-246x.2003.01915.x

3. Chapman M., Talwani M. 1982. Geoid anomalies over deep sea trenches. Geophysical J. International, 68(2): 349-369. https://doi.org/10.1111/j.1365-246x.1982.tb04905.x

4. Chekhovich V.D., Sukhov A.N., Sheremet O.G., Kononov M.V. 2019. Comparative Geodynamics of Aleutian and Izu-Bonin-Mariana Island-Arc Systems. Geotectonics, 53(1): 24-41. 
5. Coltice N., Gérault M., Ulvrová M. 2017. A mantle convection perspective on global tectonics. EarthScience Reviews, 165: 120-150. https://doi.org/10.1016/j.earscirev.2016.11.006

6. Duesterhoeft E., Quinteros J., Oberhänsli R., Bousquet R., de Capitani Ch. 2014. Relative impact of mantle densification and eclogitization of slabs on subduction dynamics: A numerical thermodynamic/thermokinematic investigation of metamorphic density evolution. Tectonophysics, 637: 20 29. https://doi.org/10.1016/j.tecto.2014.09.009

7. Dziewonski' A.M., Anderson D.L. 1981. Preliminary reference Earth model. Physics of the Earth and Planetary Interiors, 25(4): 297-356. https://doi.org/10.1016/0031-9201(81)90046-7

8. Emel'ianova T.A., Lelikov E.P. 2009. [Late oligocene-pleistocene stages of volcanism and geodynamics of the deep-sea basins of the Japan and Okhotsk seas]. In: Geologiia morei i okeanov: Materialy XVIII Mezhdunarodnoi nauchnoi konferentsii (Shkoly) po morskoi geologii, 16-20 noiabria 2009, Moskva [Geology of seas and oceans: Proceedings of the XVIII International scientific conference (School) on marine geology. 16-20 November 2009, Moscow]. Moscow: GEOS, 1: 54-58. (In Russ.).

9. Fedotov S.A., Kuzin I.P. 1963. [The velocity profile of the upper mantle in the vicinity of the southern Kuril Islands]. Izvestiia AN SSSR, Seriia geologicheskaia = Bulletin of the Academy of Sciences of the USSR: Geologic series], 5: 67-78. (In Russ.).

10. Ficini E., Cuffaro M., Doglioni C. 2019 (2020). Asymmetric dynamics at subduction zones derived from plate kinematic constraints. Gondwana Research, 78: 110-125. https://doi.org/10.1016/j.gr.2019.07.013

11. Forsyth D., Uyeda S. 1975. On the relative importance of the driving forces of Plate Motion. Geophysical J. International (Geophysical J. of the Royal Astronomical Society), 43(1): 163-200.

https://doi.org/10.1111/j.1365-246x.1975.tb00631.x

12. Gainanov A.G., Gilod D.A., Melikhov V.R. 1986. [Density modeling of the litosphere of transition zones of Pacific type]. Vestnik Moskovskogo universiteta. Seriia 4, Geologiia = Moscow University Geology Bulletin, 3: 81-88. (In Russ.).

13. Gainanov A.G., Gilod D.A., Mazurova I.S., Stroev P.A. 1987. [Gravity field and the litospheric structure of the Phillipine Sea]. Vestnik Moskovskogo universiteta. Seriia 4, Geologiia = Moscow University Geology Bulletin, 3: 70-78. (In Russ.).

14. Ganguly J., Freed A.M., Saxena S.K. 2008. Density profiles of oceanic slabs and surrounding mantle: Integrated thermodynamic and thermal modeling, and implications for the fate of slabs at the $660 \mathrm{~km}$ discontinuity. Physics of the Earth and Planetary Interiors, 172(3-4): 257-267. https://doi.org/10.1016/j.pepi.2008.10.005

15. Goes S., Agrusta R., van Hunen J., Garel F. 2017. Subduction-transition zone interaction: A review. Geosphere, 13(3): 1-21. https://doi.org/10.1130/ges01476.1

16. Grannik V.M. 1999. Reconstruction of the seismofocal zone in the East Sakhalin volcanic paleoarc: evidence from the distribution of rare earth elements. Doklady Earth Sciences, 366(1): 438-442.

17. Grannik V.M. 2017. Late Cenozoic igneous rocks of the Krilion Peninsular (Sakhalin Island). Geosistemy perekhodnykh zon = Geosystems of Transition Zones, (4): 3-20. (In Russ.). doi:10.30730/25418912.2017.1.4.003-020

18. Griggs D.T. 1972. The sinking lithosphere and the focal mechanism of deep earthquakes. In: Robertson E.C. (ed.) Nature of the Solid Earth. McGraw-Hill, 361-384.

19. Grow J.A., Bowin C.O. 1975. Evidence for high-density crust and mantle beneath the Chile Trench due to the descending lithosphere. J. of Geophysical Research, 80(11): 1449-1458.

20. Hager B.H. 1983. Subducted slabs and the geoid: Constraints on mantle rheology and flow: Technical Report (NASA-CR-170192). California Inst. of Tech., United States, 49 p.

21. Handayani L. 2004. Seismic tomography constraints on reconstructing the Philippine Sea Plate and its margin: a dissertation by submitted to the office of graduate studies of Texas A\&M University in partial fulfillment of the requirements for the degree of Doctor of Philosophy. URL:

https://pdfs.semanticscholar.org/a1e8/ba5d485994d50b5d15f6d088bbab56cf6fa9.pdf (accessed 12.01.2020).

22. Hayes G.P., Wald D.J., Johnson R.L. 2012. Slab1.0: A three dimensional model of global subduction zone geometries. J. of Geophysical Research: Solid Earth, 117(B1): B01302. https://doi.org/10.1029/2011jb008524

23. Honda S. 2017. Geodynamic modeling of the subduction zone around the Japanese Islands. Monographs on Environment, Earth and Planets, 5: 35-62. https://doi.org/10.5047/meep.2017.00502.0035

24. Hunter J., Watts A. 2016. Gravity anomalies, flexure and mantle rheology seaward of Circum-Pacific trenches. Geophysical J. International, 207(1): 288-316. https://doi.org/10.1093/gji/ggw275

25. Kimura G., Tamaki K. 1986. Collision, rotation, and back-arc in the region of the Okhotsk and Japan Seas. Tectonics, 5(3): 389-401. https://doi.org/10.1029/tc005i003p00389

26. Kogan M.G. 1975. Gravity field of the Kuril-Kamchatka Arc and its relation to the thermal regime of lithosphere. J. of Geophysical Research, 80(11): 1381-1390.

27. Krien Y., Fleitout L. 2008. Gravity above subduction zones and forces controlling plate motions. J. of Geophysical Research, 113(B9): B09407. https://doi.org/10.1029/2007jb005270

28. Makkenzi D.P. 1975. [Plate tectonics]. In: The nature of the solid Earth. Moscow: Mir, 180-209. (In Russ.).

29. Manea V., Gurnis M. 2007. Subduction zone evolution and low viscosity wedges and channels. Earth and Planetary Science Letters, 264(1-2): 22-45. https://doi.org/10.1016/j.epsl.2007.08.030 
30. McAdoo D.C. 1980. Geoid anomalies in the vicinity of subduction zones: NASA Technical Memorandum; 80678. 46 p. URL: https://ntrs.nasa.gov/archive/nasa/casi.ntrs.nasa.gov/19800019231.pdf

31. McADoo D.C. 1982. On the compensation of geoid anomalies due to subducting slabs. J. of Geophysical Research, 87(BI0): 8684 8692. https://doi.org/10.1029/jb087ib10p08684

32. Oxburg E.R., Turcott D.L. 1970. Thermal structure of island arcs. Geological Society of America Bulletin, 81(6): 1655-1688. https://doi.org/10.1130/0016-7606(1970)81[1665:tsoia]2.0.co;2

33. Peacock S.M. 2000. Thermal structure and metamorphic evolution of subducting slabs. 16 p. URL: https://www.nsf-margins.org/Eugene PDF/SubFac abstract Peacock.pdf

34. Rodnikov A.G., Zabarinskaia L.P., Rashidov V.A., Sergeeva N.A. 2014. Geodinamicheskie modeli glubinnogo stroeniia regionov prirodnykh katastrof aktivnykh kontinental'nykh okrain [Geodynamic models of the deep structure of the regions of natural disasters of active continental margins]. Moscow: Scientific World, 172 p. (In Russ.).

35. Sager W. 1980. Mariana Arc structure inferred from gravity and seismic data. J. of Geophysical Research, 85(B10): 5382-5388. https://doi.org/10.1029/jb085ib10p05382

36. Sdrolias M., Müller R.D. 2006. Controls on back-arc basin formation. Geochemistry, Geophysics, Geosystems, 7: Q04016. https://doi.org/10.1029/2005gc001090

37. Sergeev K.F. 2006. Tectonic zoning and hydrocarbon potential of the Okhotsk Sea. Moscow: Nauka, 130 p. (In Russ.).

38. Sheriff R.E. 1997. Encyclopedic dictionary of exploration geophysics. 3 rd ed. Society Exploration Geophysists.

39. Talwani M., Sutton G.H., Worzel J.L. 1959. A crustal section across the Puerto Rico Trench. J. of Geophysical Research, 64(10): 1545-1555. https://doi.org/10.1029/jz064i010p01545

40. Toksoze M.N., Sleep N.H., Smith AT. 1973. Evolution of the downgoing lithosphere and the mechanisms of deep focus earthquakes. Geophysical J. of the Royal Astronomical Society, 35(1-3): 285-310. https://doi.org/10.1111/j.1365-246x.1973.tb02429.x

41. Tosi N., Čadek O., Martinec Z. 2009. Subducted slabs and lateral viscosity variations: effects on the longwavelength geoid. Geophysical J. International, 179: 813-826. https://doi.org/10.1111/j.1365246x.2009.04335.x

42. Uerzel Dzh.L., Sherbet G.L. 1957. [Gravity interpretation on the base of standard columns of the earth crust for the oceans and continents]. In: Crust of the Earth. Moscow: [Foreign Languages Publ. House], 101-113. (In Russ.).

43. Watts A.B., Talwani M. 1974. Gravity anomalies seaward of deep-sea trenches and their tectonic implications. Geophysical J. of the Royal Astronomical Society, 36(1): 57-90. https://doi.org/10.1111/j.1365-246x.1974.tb03626.x

44. Zhang F., Lin J., Zhou Z., Yang H., Zhan W. 2018. Intra- and intertrench variations in flexural bending of the Manila, Mariana and global trenches: implications on plate weakening in controlling trench dynamics. Geophysical J. International, 212: 1429-1449. https://doi.org/10.1093/gii/ggx488 